\title{
PERKEMBANGAN PASAR MODAL
}

\section{Evi Sugiatni}

Jurusan Perbankan Syariah, Fakultas Ekonomi Dan Bisnis, Universitas Islam Negeri

Alauddin Makassar

Email : evisugiatni@gmail.com

\begin{abstract}
Abstrak
Pada masa seperti saat ini kata mengenai pasar bukannlah hal atau sesuatu yang asing bagi kita. Karena hal itu tidak dapat hindari, Oleh karena itu kita hanya bisa mempelajari dan memahami apa itu pasar dari perspektif syariahnya dan hukumnya. Jika kita berbicara tentang pasar tentunya kita juga pasti akan bertemu yang di berkaitan dengan pasar modal yaitu investasi. Seperti yang kita ketehui bahwa investasi ini yang digunakan untuk mengumpulkan beberapa hal yang berharga yang juga benilai besar. Investasi ini pada dasarnya merupakan sebuah saham yang dimana saham ini yang akan menjadi bahan atau alat yang dapat digunakan untuk melakukan transaksi di dalam pasar modal atau yang akan diperjulbelikan di dalam pasar modal. Tentunya pelaku-pelaku yang ada di dalam pasar juga merupakan sesuatu yang sangat penting.
\end{abstract}

Kata kunci : Pasar Modal, Hukum Syariah, Investasi, Saham

\section{Pendahuluan}

Seperti yang kita ketahui bahwa perkembangan yang di alami oleh sektor keuangan yang ada di suatu negara saat ini itu sangat memiliki pertumbuhan yang baik dan cukup tepat. Hal itu membuat negara menjadi negara yang dapat di ukur sebagai negara yang memiliki pertumbuhan perekonomian yang baik. Akan tetapi, hal itu tidak sepenuhnya dapat di katakan sebagai suatu negara yang memiiki sektor keuangan yang tepat. Dikarenakan sektor keuangan atau pertumbuhan perekonomian juga harus memiliki hukum dan aturannya dalam menjalankan segala aktivitas ekonominya. Sistem ekonomi dijalankan oleh hampir semua manusia akan tetapi yang lebih berperan penting di dalamnya adalah lembaga-lembaga penting di sektor keuangan. Jika kita menginginkan sistem pasar modal yang baik tentunya kita juga harus meilihat hukumnya dari pandangan islam, yang dimana hal tersebut tentunya sudah di atur dalam Al-Qur'an dan hadist ataupun di dalam sunah Nabi Muhammad SAW. Oleh karena itu kita sebagai seorang muslim sangat penting untuk memperhatikan hal 
tersebut. Hal ini kita juga akan di tuntut untuk menggunakan atau menerapkan prinsip-prinsip syariah di dalamnya. Seperti kita ketahui bahwa prinsip-prinsip syariah hanyalah bersumber dari Al-qur'an karena Al-Qur'an merupakan sumber huku islam yang paling tinggi dan kekal. Pasar modal yang akan dijalankan tentunya harus mengetahui hal-hal tersebut jika ingin menjalankan pasar modal syariah. Secara umum kita ketahui bahwa pasar modal itu merupakan sebuah alat yang digunakan oleh para investasi saham untuk memperjualbelikan aset-aset berharganya yang tentunya memiliki jangka waktu yang cukup panjang. Sedangkan pasar modal syariah adalah pasar modal yang menjalankan kegiatannya menggunakan prinsip-prinsip dan hukum islam yang tentunya bersumber utama dari Al-Qur'an dan juga pasti memiliki proses transaksi yang sangatlah terbatas. Karena menjalankan sesuatu dengan dasar hukum syariah atau islam itu harus menghindari segala perbuatan-perbuantan yang pastinya di larang oleh agama yang juga telah di atur dengan jelas di dalam Al-Qur'an tentunya. Perbuatan-perbuatan yang harus di hindari itu merupakan perbuatan yang memiliki banyak dampak negatif daripada dampak positifnya untuk jangka waktu yang sangat panjang.

Dalam memahami pasar modal kita juga akan mempelari hal yang utama di dalamnya yaitu investasi. Investasi tentunya sudah dikenal oleh bayak orang dan bahkan telah ada di masa lalu yaitu masa penjajahan beberapa negara yang ada di masa lalu. Akan tetapi, investasi yang ada di dalam atau yang di jalankan di pasar modal itu beru di mulai pada saat pemerintahan yang di jalankan oleh Pemerintahan Hindia-Belanda. Yang dimana saat itu Pemerintah Hindia-Belanda mendirikan sebuah lembaga yang dimana lembaga itu dinamakan sebagai Amsterdamse Effectenbureurs. Lembaga ini lebih tepatnya ada di Batavia pada tahun 1912. Fungsi dari lembaga ini tidak lain sebagai sumber pembiayaan pada saat itu. Menurut Karim dalam Hamidi (2003, 268) peluncuran pasar modal syariah ini menjadi penting karena banyak ketentuan baru yang akan dikeluarkan Bapepam (Huda, 2015).

\section{PEMBAHASAN}

A. Pengertian Pasar Modal.

Pasar modal merupakan sebuah pasar yang memiliki sistem operasi yang secara terorganisis yang dimana di dalamnya terdapat sebuah aktivitas perdagangan surat-surat atau aset-aset berharga yang jenisnya bermacam-macam diantarnya yaitu saham, ekuitas, surat pengakuan hutang, obligasi dan surat berharga lainnya. Adapun yang mengartikan pasar modal secara berturut-turt yaitu Hugh T. Patrick \& U Tun Wai menyebutkan 3 (tiga) definisi pasar modal; 
Pertama, dalam arti luas, pasar modal adalah keseluruhan sistem keuangan yang terorganisir, termasuk bank-bank komersil dan semua perantara di bidang keuangan, surat berharga/klaim jangka pendek panjang primer yang tidak langsung. Kedua, dalam arti menengah, pasar modal adalah semua pasar yang terorganisir dan lembaga-lembaga yang memperdagangkan warkat- warkat kredit (biasanya yang berjangka lebih dari 1 tahun) termasuk saham, obligasi, pinjaman berjangka, hipotek tabungan dan deposito berjangka. Ketiga, dalam arti sempit, pasar modal adalah tempat pasar teorganisir yang memperdagangkan saham dan obligasi dengan menggunakan jasa makelar dan under writer (Yafiz, 2008).

Investasi yang secara umum diartikan sebagai suatu proses atau kegiatan penanaman aset atau sebuah dana yang dapat dilakukan oleh sebuah perusahaan ataupun dapat dilakukan oleh pihak perorangan yang bertujuan untuk memperoleh keuntungan timbal balik yang besar dan tentunya dengan waktu yang terbatas. Dalam prosesnya dana yang di masukkan atau dana yang disntikkan ke dalam sebuah usaha akan di jalankan oleh pasar modal atau akan dikelolah oleh pihak pasar modal. Sama seperti yang kita ketahui bahwa di dalam pasar akan terjadi sebuah proses kegiatan jual-beli barang akan tetapi yang membedakan antara pasar biasa dan pasar modal adalah apa yang di perjualkan di dalamnya atau alat yang melangsungkan proses kegiatannya itu berjalan dengan baik. Di dalam pasar biasa yang terjadi adalah jual beli barang tetapi di dalam pasar modal yang di perjual belikan adalah saham atau dana yang telah di suntikkan. Karena hal itu juga terkadang persentase di dalam pasar modal melebihi tingkat persentase inflasi yang ada di dalam suatu negara. Hal itu disebabkan oleh beberapa faktor diantaranya adalah Kerena kegiatan jual beli saham yang ada di pasar modal itu lebih tinggi. Maka dari itu sebelum kita melakukan atau menjalankan kegiatan investasi ini di dalam pasar modal kita harus terlebih dahulu mengetahui siapa saja pelaku yang terlibat di dalam pasar modal tersebut. Karena seperti yang kita ketahui bahwa di Pasar kita akan menjumpai atau menemukan para penjual dan pembeli. Akan tetapi berbeda halnya dengan pasar modal, di pasar modal kita akan menjumpai jenis pasar yang dimana pasar jenis ini merupakan pemegang dana yang sangat besar baik dana yang berasal dar masyarakat maupun organisasi yang ada di dalam negara sehingga dana yang di pegang oleh pasar jenis ini adalah dana yang cukup 
komplek. Para pelaku yang terlibat dalam kegiatan pasar modal yaitu : Emiten, Investor, Penjamin Emisi, Agen penjual dan Pialang ( broker ).

Di saat seperti ini kita harus bisa membedakan pasar modal yang di jalankan oleh pihak kapitalisme dan yang dijalankan oleh pihak syariah. Untuk ini ada beberapa prinsip yang dapat kita gunakan untuk mengenali pasar modal syariah yaitu Ibn Taimiyah mengemukakan beberapa ciri dan prinsip pasar sebagai implikasi dari doktrin kebebasan ekonomi dalam Islam sebagai berikut: 1) setiap orang bebas masuk dan meninggalkan pasar; 2) harus ada informasi yang jelas mengenai kekuatan pasar dan barang-barang dagangan (komoditi); 3) tidak boleh ada unsur-unsur monopoli; 4) haram hukumnya melakukan penyimpangan dari prinsip kebebasan ekonomi yang yang jujur, seperti melakukan sumpah palsu, takaran yang tidak tepat, dan niat buruk. Islam juga melarang produksi dan distribusi komoditi yang tercela, karena merusak kesehatan dan tatanan moral yang berlaku. (Wiyanti, 2013).

Pasar Modal tidak hanya dijalankan begitu saja dengan bebas akan tetapi juga memiliki pengawas khusus di bidang Pengawas Pasar Modal. Pengawas itu dinamakan atau lebih dikenal dengan istilah BAPEPAM ( Badan Pelaksana Pasar Modal). Ada beberapa lembaga yang akan mendukung berjalannya poses kegiatan pasar modal yaitu :

\section{Badan Pengawas Pasar Modal ( BAPEDAM )}

Lembaga ini melaksanakan tugas di bidang pembinaan, pengaturan dan pemgawasan dalam seluruh kegiatan di dalam pasar modal.

\section{Bursa efek}

Lembaga ini juga merupakan lembaga yang memiliki tanggung jawab yang cukup besar seperti lembaga penunjang lainnya. Lembaga ini di tugaskan untuk bertindak sebagai penyelanggara, dan pengatur sistem yang digunakan untuk penawaran permintaan saham di pasar modal.

3. Lembaga Kliring Dan Penjamin 
Lembaga ini bertugas untuk pendukung di pihak penyelenggaraanya di dalam sistem pasar modal yang secara menyeluruh.

4. Lembaga Penyimpanan Dan Penyelesaian.

Lembaga ini bertugas untuk menyelenggarakan sebuah tempat penyimpanan terpusat.

B. Jenis-Jenis Pasar Modal.

\section{Pasar Perdana}

Pasar perdana merupakan tempat dimana seluruh aset dan surat-surat berharga di perjualbelikan atau di perdagangkan untuk yang pertama kali, sebelum di catat oleh pihak lembaga Bursa Efek. Jika kita melakukan sebuah proses pembelian surat berharga sebelum IPO maka kita masi bisa mendapatkan harga saham yang sesuai dan jumlah yang telah di tentukan.

2. Pasar Sekunder

Pasar sekunder merupakan tempat dimana seluruh aset yang telah melalui proses penjualan di akhir perdana. Di pasar sekunder proses jual-beli itu dapat terjadi diantara investor yang satu dengan investor lainnya. Pada Pasar ini harga saham itu bersifat fluktualif.

C. Hukum pasar modal

Secara mekanisme pasar hukum pasar yang perluh untuk kita ketahui ada 4 yaitu :

1. Spot

Pasar Spot merupakan sebuah pasar yang dimana pasar ini bertujuan untuk pembelian atau penjualan seluruh istrumen keuangan, komoditas atau aset-aset berharga dengan transaksi pembayaran tunai dan langsung, Sehingga untuk ini pasar ini menggunakan pengiriman masa depan ( future atau forwards), atau biasa juga disebut dengan pasar tunai. 
2. Tranding On Margin

Tranding Margin ini merupakan pasar yang bertujuan untuk memfasilitasi para pedagang-pedagang saham yang dimana mereka dikenal dengan istilah treder dengan pinjaman perusahaan sekuritas, yang bertujuan untuk membeli saham-saham yang sedang berpotensi bagus. Margin trending adalah metode pembelian saham dengan cara meminjam sejumlah uang dari perusahaan sekuritas atau yang dikenal dengan istilah broker.

3. Short Sale

Transaksi shortselling merupakan sebuah transaksi penjualan efek di mana efek yang di maksud adalah tidak memiliki oleh penjualan pasa saat transaksi dilaksanakan. Artinya shortselling yang secara sederhana disebut jual kosong, Karena transaksi dilakukan tanpa ketersediaan efek.

4. Option

Option merupakan sebuah perjanjian atau kontrak antara penjual opsi ( Seller atau writer) dengan pembeli opsi ( buyer ), dimana penjual opsi akan menjamin adanya sebuah hak bukan sebuah kewajiban dari opsi itu, sehingga untuk itu membeli ataupun menjual sebuah aset tertentu pada waktu dan harga yang telah ditentukan atau yang telah ditetapkan. Opsi ini merupakan sebuah intrumen keuangan yang telah diciptakan oleh bursa, bukan diciptakan oleh perusahaan, dibeli dan dijual terutama oleh investor, penting bagi investor maupun manejer keuangan.

Pasar modal syari'ah dapat diartikan sebagai sebuah kegiatan yang dilakukan dalam pasar modal sebagaimana yang diatur dalam UUPM yang tidak bertentangan dengan prinsip syariah. Oleh karena itu, pasar modal Syariah bukanlah suatu sistem yang terpisah dari sistem pasar modal secara keseluruhan. Secara umum kegiatan pasar modal syariah tidak memiliki perbedaan dengan pasar modal konvensional, namun terdapat beberapa karakteristik khusus pasar modal syariah yaitu bahwa produk dan mekanisme transaksi tidak bertentangan dengan prinsip-prinsip syariah.

Berdasarkan ketetapan majma' fiqh islami, maka kriteria pasar modal syari'ah adalah : 
- Saham yang ditransaksikan di pasar modal syariah haruslah berasal dari perusahaan yang memproduksi barang dan jasa yang halal saja.

- Bentuk transaksi saham yang diperbolehkan adalah transaksi spot dan transaksi masa sekarang.

- Semua bentuk obligasi dan turunannya adalah haram untuk ditransaksikan.

D. Fungsi Pasar Modal

Ada beberapa fungsi dari pasar modal ini, beberapa fungsi pasar modal akan kita bahas yaitu :

1. Pasar modal sebagai sarana penambah modal bagi sebagian usaha dari perusahaan yang dapat memperoleh dana dengan cara menjual saham ke pasar modal. saham-saham ini akan dibeli oleh pihak masyarakat umum, perusahan-perusahaan lain, lembaga, ataupun akan dibeli oleh pihak pemerintah.

2. Pasar modal juga sebagai pemerataan pendapatan. Setelah jangka waktu tertentu, saham-saham yang telah dibeli akan memberikan deviden ( yaitu bagian dari keuntgan keuangan ) kepada para pembelinya. Oleh karena itu, penjualan saham melalui pasar modal dapat dianggap sebagai sarana pemerataan pendapatan.

3. Pasar modal sebagai sarana peningkatan kapasitas produksi. Dengan adanya tambahan modal yang diperoleh dari pasar modal, maka produktivitas pruduktivitas perusahaan akan meningkat.

4. Pasar modal modal sebagai sarana penciptaan tenaga kerja. Keberadaan pasar modal dapat mendorong dan akan berkembangnya industriindustri lainnya yang akan berdampak pada terciptanya lapangan kerja baru.

5. Pasar modal sebagai saran peningkatan pendapatan dari negara. Setiap deviden yang telah didapatkan atau dibagikan kepada para pemegang saham akan dikenakan sebuah pajak oleh pemerintah. Adanya tambahan pemasukan pemerintah melalui pajak ini sehingga membuat negara dapat meningkatkan pendapatan negara.

6. Pasar modal sebagai indikator perekonomian negara. Aktivitas dan volume penjualan ataupun pebelian di pasar modal yang semakin mengkat atau semakin padat untuk memeberikan sebuah indikasi bahwa 
aktivitas bisnis berbagai perubahan berjalan dengan baik. Begitu pula dengan sebaliknya.

E. Intrumen Investasi Pasar Modal

Pasar modal juga dikenal dengan istilah bursa efek. Di dalamnya, kamu bisa menemukan berbagai jenis surat berharga yang setiap hari diperdagangkan. Jenis-jenis surat berharga yang dapat digunakan yaitu :

1. Saham

Saham merupakan salah satu surat yang berharga yang akan menjadi bukti kemelikan atas sebuah perusahaan. Investor yang memiliki saham di sebuah perusahaan, maka investor ini berhak untuk mendapatkan deviden atau pembagian laba bersih.

2. Reksadana

Reksadana dikenal sebagai sebuah intrumen investasi yang dapat menjadi sebuah wadah yang bertujuan untuk pengumpulan serta pengelolaan dana dari beberapa investor. Dana tersebut kemudian dikelola oleh pihak menejer investasi sehingga akan menjadi sebagai sebuah intrumen, seperti pasar uang, obligasi, saham, atau efek lainnya.

3. Surat Utang Atau Obligasi.

Kita juga dapat mendapatkan sbeuah surat berharga yang berupa obligasi di pasar modal. Kepelikan surat utang itu dapat dipindahkan ke tangan orang lain, dan pemegangnya akan memiliki hak untuk memeperoleh bunga serta pelunasan utang pada jangka waktu yang telah di tentukan.

4. Exchange Traded Fund (ETF)

Surat berharga jenis ini sebenarnya emiliki kemiripan dengan redaksana, sama-sama dapat dikumpulkan secarakolektif. Akan tetapi ETF bisa diperdagangkan di bursa efek layaknya sebuah saham.

5. Derevatif

Selanjutnya, ada pula surat berharga yang berbentuk atau di sebut dengan derevaktif. Surat jenis ini dikenal sebagai jenis bentuk turunan dari saham. Derevaktif terdapat 2 jenis yang bisa kita temukan di dalam pasar modal terutama di pasar modal yang ada di Indonesia, yaitu Warrant dan Right. 


\section{F. Manfaat Pasar modal}

Pasar modal juga memiliki manfaat bagi emiten atau lebih dikenal sebagai pihak yang sedang melakukan penawaran umum, yaitu penawaran efek yang dapat dilakukan oleh Emiten untuk menjual efek kepada masyarakat berdasarkan tata cara yang telah di atur dalam peraturan Undang-undang yang berlaku.

Manfaat pasar modal untuk emiten

1. Jumlah dana yang dapat akan dihimpun dengan jumlah yang besar.

2. Dana tersebut dapat diterima sekaligus pada saat perdana selesai.

3. Tidak ada convenant sehingga manajemen dapat lebih bebas dalam pengelolaan

4. Solvabilitas perusahaan tinggi sehingga memperbaiki citra perusahaan

5. Ketergantungan eiten terhadap bank menjadi lebih baik

Manfaat pasar modal untuk investor

1. Nilai investasi berkembang mengikuti pertumbuhan ekonomi

2. Memperoleh dividen bagi mereka yang memiliki atau memegang saham

3. Dapat sekaligus melakukan investasi dalam beberapa intrumen yang menguransi risiko.

\section{PENUTUP}

Berdasarkan materi yang telah di sampaikan di atas hal yang penting untuk diketahui bahwa pasar modal merupakan bagian penting dalam sistem perekonomian yang besar. Semakin baik prose jalannya pasar modal maka akan semakin baik pula sektor keuagan yang dimiliki maka demikian pula dengan sistem perekonomian. Pasar modal adalah kegiatan yang dijalankan untuk membentuk suatu sistem ekonomi sehingga Untuk memperbaiki sistem perekonomian kita harus memperhatikan pasar modal yang sedang berjalan. Dan juga tentunya harus memperhatikan beberapa unsur atau prinsip syariah yang ada di dala islam. Jika kita baru ingi memiliki niat untuk melakukan kegiatan investasi. Mungkin kita bisa mempertingkatkan obligasi sebagai produk investasi terbaik. Memang, obligasi tidak memiliki popularitas seperti saham sebagai produk investasi, namun obligasi bisa jadi pintu masuk kita dalam memulai berinvestasi yang dapat menambah penghasilan kita sesama orang yang masih produktif. 


\section{DAFTAR PUSTAKA}

Ali, F. (2016). Pasar Modal Syariah. Perbankan Syariah dan Pasar Modal Syariah, 1-11.

Arifardhani, Y. (2020). Hukum Pasar Modal Di Indonesia. Jakarta : KENCANA ( Devisis Prenada media Group ).

Fadilla. (2018). Pasar Modal Syariah Dan Konvensional. Perbankan Syariah Dan Pasar Modal Syariah, 3(2), 45-55.

Huda, N. (2015). Perkembangan Pasar Modal Syariah Di Indonesia. Hukum Permodalan ekonomi islam, 3(2), 63-77.

Latifah, A. (2016). Pengaruh Sektor Perbankan Syariah dan Pasar Modal Syariah Terhadap Finansial Deepening Di indinesia. Perbankan Syariah dan Pasar Modal Syariah, 7(2), 107-130.

Wiyanti, D. (2013). Persektif Hukum Islam Terhadap Pasar Modal Syariah Sebagai Alternatif Investasi Bagi Investor. Aspek Hukum Pasar Modal Syariah, 20(2), 234-254.

Yafiz, M. (2008). Saham dan Pasar Modal Syariah: Konsep, Sejarah dan Perkembangannya. Aspek Hukum Pasar Modal Syariah, 32(2), 3-28. 